
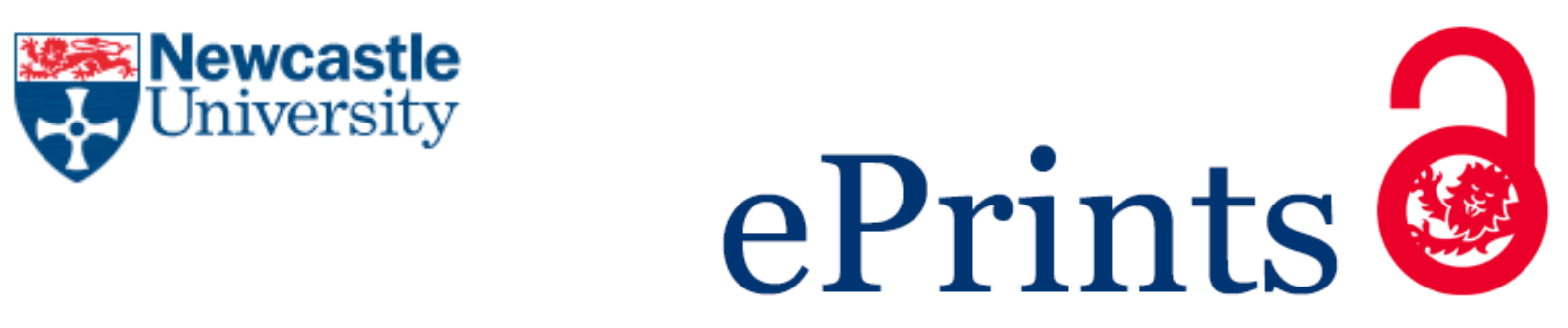

Wells R. Fact and Responsibility: Approaches towards the Factual in Contemporary Art. Zeitschrift für Ästhetik und Allgemeine Kunstwissenschaft 2015, 60.1(Special Issue).

\title{
Copyright:
}

(C) 2015 Felix Meiner Verlag GmbH

Details of issue:

https://meiner.de/periodika/zaek/zeitschrift-fuer-aesthetik-und-allgemeine-kunstwissenschaft-band-60heft-1.html

Date deposited:

$28 / 09 / 2015$

Embargo release date:

20 August 2016

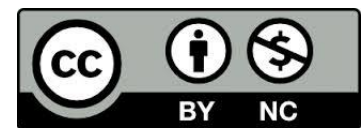

This work is licensed under a Creative Commons Attribution-NonCommercial 3.0 Unported License 


\section{Fact and Responsibility: Approaches towards the Factual in Contemporary Art}

Rachel Wells

Alfredo Jaar's Untitled (Newsweek) (1994) is an artwork that is reliant upon fact. In a series of pointed juxtapositions, statistics and reported events from Rwanda are contrasted with the various preoccupations adorning the front covers of the American publication Newsweek. Headline images of Kurt Cobain, Richard Nixon, Jackie Kennedy and OJ Simpson, amongst others, are paired with deadpan statements conveying the latest events in the developing Rwandan genocide, followed by a number of the dead. For example, underneath a Newsweek cover dedicated to America's hosting of the football world cup, Jaar's caption reads:

June 17, 1994: France announces its plan to send 2,500 troops to Rwanda as an interim peacekeeping force until the UN troops arrive. 700,000 deaths.

Such short, unembellished statements tell of a growing horror. Throughout the series, Jaar is by no means encouraging a questioning of his reportage; rather he is using the status of fact as a means to glare, cold and hard, into our ability to ignore and overlook what is going on 'elsewhere'. There is no trace here of a postmodern reluctance to accept a fixed viewpoint, no worrying over an essential incommensurability or the perceived arrogance of truth-telling. Rather, there is an urgency in the conveying of news, highlighted by its absence in Newsweek. Untitled (Newsweek) suggests that fact must be communicated, and if not through conventional sources such as newspapers, then through art, which, it is implied, offers an effective alternative. In Jaar's work, art is in the service of fact: it offers fact a safe-haven and an important platform when it is either attacked or ignored elsewhere.

This conception of the relationship between art and fact is unconventional, to say the least. Art and fact have long been considered as contrasting, if not directly oppositional, tendencies. Art is frequently conceived as a product of imagination, of subjective creativity, whereas fact is a cold matter of the objective and indisputable. Under postmodernism, this opposition was often configured as antagonistic, as many artists sought to emphasise the 
instability of 'truth' via an illumination of the flaws of representational systems. Fact was no longer merely distant from art but was frequently under direct attack from it. Yet over the last two decades, a tendency has arisen in international art that is concerned with the presentation of fact, not in order to undermine it, or to question its legitimacy, but, as with Jaar's work, to applaud and often to use it. ${ }^{1}$ This paper will argue that this tendency has emerged in two distinct strands, both of which underline the decline of a postmodern insistence on unknowability. The first strand is that of a resurgence of politically engaged art practices which aim to draw viewers' attention towards facts of suffering and injustice. The second is that of a conceptual art practice that relies upon an extreme minimalism in order to deny artistic freedom and subjectivity as far as possible. I will outline both tendencies by considering the work of Jaar, Martin Creed and Jeremy Deller as examples, and will conclude by considering the different conception of responsibility that each strand of contemporary art suggests towards the finding, recording and communicating of facts.

Jaar's work clearly falls under the first category, and it has recently been identified as part of a related resurgence of documentary art practices over the last twenty years. Julian Stallabrass has analysed the conditions for this „reawakening“ of documentary, suggesting that economic globalisation and its structural reflection in the art world, technological advancements including the mass participation now facilitated by social media, and renewed political fervour following the attacks of September $11^{\text {th }} 2001$ and subsequent conflicts have all contributed to its rise. ${ }^{2}$ As Stallabrass also notes, this documentary tradition is based in artistic mediums that have a long and established relationship to 'truth': the indexicality of photography and film has lent them more easily to a presentation of fact than other artistic media such as painting, sculpture, performance or installation. However, this paper will argue that here too, in these more traditionally rarified and subjectively fashioned media, there has also been a resurgence of interest in the factual, and that this interest is often related to an address of responsibility - be it the artist's or the viewer's - that lies at the heart of the artwork.

\footnotetext{
$1 \quad$ Alongside such an interest in the factual, there has also been a growth in what Julian Stallabrass has termed 'documentary fictions', which he suggests is an attractive alternative for artists who are keen to present their own unique expression, avoid appearing naive, and who want to comment implicitly upon the nature of a documentary tradition. (Julian Stallabrass: Documentary-Documents of Contemporary Art, London and Cambridge, Massachusetts, 2013, 19.) Such explorations of fact through fiction are clearly distinct from the practice of the artists discussed here.
}

Ibd., 12. 


\section{Causality as the basis of fact}

Jaar's Untitled (Newsweek) is obviously heavily reliant on photography. But he has made other works that do not rely on the indexical nature of the medium in order to communicate fact. His 1999 artwork Lights in the City involved the installation of light switches in several hostels for homeless people in Montreal, all of which triggered a bright red light to illuminate in the city's landmark monument, the Cupola of the Marché Bonsecours. Whenever a homeless person entered one of the hostels, they were invited to press the switch, thereby sending a visual warning sign to the rest of the city that one of its inhabitants was without a permanent shelter. Whilst bypassing traditional documentary media, then, Lights in the City nevertheless is dependent upon viewers' acceptance of the truthfulness of what Jaar has termed a ,distress signal“. ${ }^{3}$ The flashes of red light are a visualisation of information; they are designed to function as a communication of fact. Despite the lack of photography or film, Jaar still relies upon a straightforward causality of events in order to draw attention to what is too easily overlooked. As Hume famously stated in his Enquiry Concerning Human Understanding, ,all reasonings concerning matter of fact seem founded in the relation of cause and effect. By means of that relation alone we can go beyond the evidence of our memory and senses“. ${ }^{4}$ Jaar's practice by no means suggests Hume's following caveat that there is no rational support for believing in causation, however. While Hume argues that there is no logical reasoning behind our expectations for similar events to arise from similar causes, ${ }^{5}$ the repetition of the flashing beacon in Lights in the City offers no comfortable diversion from the pattern of one person after another finding themselves in the same precarious situation. Indeed, Jaar's use of light here, that precondition of vision, only emphasises what is too easily unseen. Again, then, art is in the service of fact, and those facts are directed at those for whom they will be hard, uncomfortable, distressing.

\footnotetext{
3 Alfredo Jaar: 'Notes on Lights in the City', 2000, http://www.alfredojaar.net/main.html, accessed April 2014.

$4 \quad$ David Hume: An Enquiry Concerning Human Understanding, ed. by Peter Millican, Oxford, $2007,19$.

$5 \quad$ Ibd., 29. Hume states that 'it is not reasoning which engages us to suppose the past resembling the future, and to expect similar effects from similar causes, which are, to appearance, similar'.
} 
The politicised emphasis of Jaar's work marks him out as one of a growing number of international artists who have sought to draw viewers' attention towards situations of war, violence, suffering and injustice through a visual communication of fact. Yet there is another contemporary strand of artwork which also relies upon an extreme reduction of subjectivity, but which uses such factual means for a very different end. These are conceptual art practices which frequently rely upon an extreme minimalism in order to reduce representation to presentation. One prominent example is the work of Martin Creed, which frequently bears the mark of a desire to expunge his own artistic decision making from the existence of the final artwork. A year after Jaar's Lights in the City, Creed made his Turner-prize winning Work No. 227: The Lights Going On And Off (2000). As with Jaar's work, there is an extreme simplicity in the artistic gesture: a light flashes on and off at regular intervals, this time within the gallery. While Creed's installation clearly lacks the social urgency of Jaar's politicised 'lighthouse', the apparent meaninglessness of Creed's light flashes only emphasises his isolation of the essential 'fact' of the gesture's minimal existence. Other works by Creed share this apparent desire to present only the most definite and objective form of artistic making. Speaking about his recent works which have focused upon involuntary actions, Creed has suggested he is continually searching for a kind of making that requires minimum preparatory thought. He has discussed his Shit and Sick Films, such as Work No. 503 (2006) and Work No.600 (2006), which show individuals defecating and vomiting in white gallery spaces, in terms of a lack of control, of „,doing something without thinking“": ,in other words, I wanted my work to be more like a vomit than a rumination“. ${ }^{6}$ Art here may not be in the service of fact, but it appears desperate to reach it; each artwork reveals an instinct to avoid individual expression, decision making, and the freedom of open subjectivity and instead to become synonymous with the basic, undisputable and impersonal nature of fact.

Indeed, Creed has discussed his favourite artworks as those „,where the end seems inescapable as the only possible result", thereby avoiding any need for artistic decisions. ${ }^{7}$ Here then is another shared pursuit of the simple causality of fact: Creed's work, like Jaar's, seeks to be reliant upon the relationship between cause and effect. Any decision making outside of this causal inevitability is conceived of as directly ,problematic“, so that

6 Martin Creed: Artist's Talk, Birmingham Institute of Art and Design, Margaret Street, 3 October 2008, transcript, 2. Available at: http://ikon-gallery.org/wp-content/uploads/2013/08/c5d34452-66a6-450e-8a4ef15e9b3536d8.pdf accessed October 2009.

7

Ibd., 6. 
„Problems come in works where there may be more than two or three solutions that seem to be equally good.“8 Instead, Creed prefers works such as Work No. 409 (2005), the installation of an audio recording of singing voices within a lift"

The voices simply go to the lowest of the bass to the highest of the soprano. Once the parameters of the work are set, the work makes itself. It's a matter of dividing the range of voices over the journey of the lift. That's another piece where the end result is inescapable after the work is set in motion.

In contrast, Creed notably deems some of his work as less ,perfect“ if it has „,more grey areas“ or if „,it's more down to feelings.“"10 Throughout his oeuvre, Creed seems to be searching for the complete removal of his artistic subjectivity, and to present viewers instead with a minimal action or mark that is, as far as possible, drained of individual intention or assertion.

Jeremy Deller has also explored fact through artwork that is not reliant upon traditionally documentary media. His 2009 It is what it is saw Deller and a small team travel across the US with the remains of a car that had been destroyed in the 2007 suicide bomb attack on Al-Mutanabbi Street in Baghdad. The wrecked car embodied the deathly effects of the bomb: it told of a straightforward, disastrous causality between explosion and destruction. Indeed, Deller has been careful never to describe the charred remains of the vehicle as an artwork; rather he refers to it as a relic, and exhibit, ,, a piece of evidence“"11. this is an object which supports a collection of facts. The artwork itself then consisted in the presentation of the wreck to people along Deller's ,road trip“, and the conversations that it prompted between these local people and Deller's travelling team. With Deller and curator Nato Thompson were Esam Pasha, an Iraqi artist who had sought asylum in the US in 2005, and Jonathan Harvey, a US army reservist who had fought in Iraq. Deller's own description of the

\footnotetext{
$8 \quad$ Creed: Artist's Talk, [note 6], 6-7.

$9 \quad$ lbd., 6-7. Jeremy Deller: Artist's talk, Imperial War Museum, London, $11^{\text {th }}$ September 2010.
} 
project presents a matter-of-fact approach which emphasises the status of his artwork as documentable ${ }^{12}$ :

On March 5, 2007, a large bomb was detonated in the book market on Al-Mutanabbi Street in Baghdad. Thirty-eight people were killed and hundreds more injured. Two years later, I towed a car destroyed in this attack across the United States along with a US army reservist and an Iraqi citizen. Along the way we stopped in public spaces in fourteen cities to chat with passersby. This book is a document of our journey and the people we met along the way.

Deller's central aim seems to be the generation of conversation and debate, and its neutral recording. As with Jaar's Untitled (Newsweek), there is a clear determination to create artwork which engages with central, current, urgent political issues, and, as with Jaar's work, facts are central to the artwork and are never encouraged to be questioned or undermined. In some ways, Deller's project is more direct: while Jaar's tactics centre upon the absence of visual information, with written factual statements alongside images that reveal the looking away of the US, Deller's approach is to confront the US with a visual fact itself. Yet while the absent images in Jaar's artwork result in an acute politicised point, the physically present object in Deller's artwork opens out as a neutral prompt to others' reactions. Both make US reaction the focus of the artwork, but while Jaar expresses his own clear judgement about that reaction, Deller is meticulous in neutrally presenting this reaction as fact itself.

Indeed, the neutrality of Deller's project is deliberate and painstaking. When asked why they chose this vehicle, and not one destroyed by coalition forces, Deller and Thompson stated that they had limited choice about what they could remove from Iraq, and that they are „deliberately trying to avoid“ making an anti-war statement. Rather, Dellar states that „the attack on Al-Mutanabbi Street would never have happened if the invasion had not gone ahead and had not been so poorly planned. So there is a collective responsibility“. ${ }^{13}$ As with Creed, Deller seems determined to reduce his own subjectivity as far as possible. Having created a powerful and shocking way of confronting those living miles away from Iraq with the effects of the war, Deller's project was aimed at prompting, teasing out, the subjective view of others, and documenting these views as facts, but there is also a sign of a desire to limit his

\footnotetext{
12 Jeremy Deller: It is what it is: conversations about Iraq, New York, 2010, back cover. lbd., 15.
} 
own artistry to the presentation of the factual. Deller's wider practice also offers a complex mixture of both artistic approaches towards fact outlined in this paper. As an artist interested in participatory art practice, his work is frequently discussed in terms of being both politically engaged and clearly resistant to taking a position himself. Stuart Hall has summed up this aspect of Deller's work as offering „politics for a so-called non-political age“, suggesting that it is not clear as to ,whether [Deller's] main objective is to shatter, disrupt, provoke, enlist or even change minds“. ${ }^{14}$ Deller's interest in politics and in people apparently results in a desire to present, and even to produce facts through his work, but to go no further: It is what it is starts and ends with the factual. Rather like the repetitious title of the project, a phrase laced with resignation and a lack of personal responsibility, facts are the constituent assertion within the work: the beginning and the end of the project have the same factual basis.

Jaar, Creed and Deller's artwork then attempts to avoid the subjective and rely instead upon the factual, and notably each oeuvre also presents the factual in terms of causation; even when avoiding the indexicality of photography or film, each artist relies upon the relation of cause and effect to sidestep artistic subjectivity. Creed and Deller's approaches share with Jaar's an unquestioning, ironically rather untroubled attitude towards the reliability of causation, contra Hume. Indeed, I want to suggest that these artistic approaches to fact bear closer resemblance to Kant's understanding of the relationship between fact and causality, and that the connection of this model to Kant's moral philosophy is an illuminating framework within which to consider each artist's approach to responsibility.

\section{Responsibility as an effect of fact}

Each artist's interest in the factual results from clearly different personal impulses: whilst Jaar's work emerges from an overt desire to discover and disclose facts of a social and political nature, Creed's work suggests an equally overt reluctance to construct meaning or value beyond the factual. Deller's work shares Jaar's provocative presentation of fact and Creed's resistance to taking an authorial position himself, whilst keen to incorporate others' reactions to fact as the very substance of his work. However, whilst Deller is fastidious in his

\footnotetext{
14 Stuart Hall: 'Jeremy Deller's Political Imaginary', in: Joy in People - Jeremy Deller, London, 2012, 81-89, 87,89
} 
desire not to influence his participants in any way, both Jaar and Creed convey messages to their viewers, however oppositional in nature: while Jaar's work seems intent upon prompting concern, Creed emblazons the words „Don't Worry“ in neon yellow light across the corner walls of a white cube space in Work No. 290 (2003); Jaar's work is relentless in its highlighting of horror and suffering, Creed's ostensibly seeks to reassure, with „Everything is Going to be Alright" writ large across the frontage of neoclassical galleries, as in Work No. 289 (2003). While Jaar's practice appears to emerge from a desire to discover and disclose facts, Creed's work reveals a desire intent on eliminating the subjective. Jaar's work serves fact and suggests complete confidence in it; Creed's resorts to fact as a result of radical uncertainty; Deller's project seems to offer a combination of the two.

Each impulse, though, however oppositional, arises from a strong sense of artistic responsibility. Jaar's oeuvre presents a persistent questioning of his own, the viewer's, and wider society's sense of responsibility. Georges Didi-Huberman has discussed Jaar's work alongside that of Allan Sekula and Martha Rosler as a „turning of the document into a political critical tool“, while Val Williams has used the term the „responsible gaze“ in order to discuss Jaar's work. ${ }^{15}$ Creed's sense of responsibility is perhaps less explicit, but his discussion of his work reveals an acute, almost debilitating, awareness of it. In an interview from 2002, Creed was asked whether his desire for 'decisions to make themselves' in his work was ,an avoidance of responsibility“. His response was clearly one of surprise ${ }^{16}$ :

No, no, I think it's the opposite, isn't it? [...] I don't think it's an avoidance of responsibility. I think that the fear comes from thinking, you know, I'm responsible for this. Therefore I don't want to get it wrong, [...] So if responsibility comes into it, it's in that way. In the sense that you're responsible for what you do and that affects other people and can't be separated from other people really, or from anything else.

An acute awareness of cause and effect in terms of responsibility - the awareness that actions (and inaction) will have effects on others - has manifested itself in both artistic tendencies as a reliance upon the causal properties of fact. What differentiates these artists most significantly, perhaps, is the order of the causal chain between fact and responsibility in their

15 Georges Didi-Huberman: 'Emotion Does Not Say “I”: Ten Fragments on Aesthetic Freedom', in: Alfredo Jaar, Zurich, 2007, 57-69, 67. 
work: while fact seems to prompt Jaar to a sense of urgent social responsibility, an acute sense of artistic responsibility seems to throw Creed towards the creation of artworks reliant upon fact. Deller, as suggested above, seems keen both to start and end his projects with the factual.

This creates a rather Kantian view of Jaar's approach, in that the empirical law of causality remains separated from a transcendental freedom to act upon the facts that he has revealed. While Kant shares Hume's assertion that fact is grounded in causality: ,the relation of cause and effect forms the condition of the objective validity of our empirical judgements" ${ }^{17}$ his divergence from Hume is clear in his declaration of the limits of this causality. As Roger Scruton has summarised, for Kant, causality is limited to the empirical realm, whereas freedom belongs to the transcendental realm, to which 'categories such as causality do not apply'. ${ }^{18}$ The independence of the transcendental self from the causality of nature is set out clearly in Kant's Groundwork of the Metaphysic of Morals, in which he states „For that a thing in the appearance (belonging to the world of sense) is subject to certain laws from which just the same as a thing or a being in itself is independent, contains not the least contradiction“. ${ }^{19}$ The result, for Kant, is that the paradigm of free action cannot be attributed to empirical causality, but instead, as Roger Scruton has summarised, arises spontaneously out of the rational processes that constitute an individual's will. ${ }^{20}$ Kant highlights the inapplicability of causation to individual will in the Groundwork ${ }^{21}$ :

As a rational being, hence as one that belongs to the intelligible world, a human being can never think of causality of his own will otherwise than under the idea of freedom; for independence from the determining causes of the world of sense (such as reason must always ascribe to itself) is freedom.

\footnotetext{
17 Immanuel Kant: Critique of Pure Reason, trans. Marcus Weigelt, London, 2007, 221. Roger Scruton: Kant - A Very Short Introduction, Oxford, 2001, 75.

19 Immanuel Kant: Groundwork of the Metaphysics of Morals, trans. and ed. by Mary Gregor and Jens Timmermann, Cambridge, 2012, 66. Scruton: Kant [note 18], 80. 
Freedom, then, by definition, is independence from causality. And an acknowledgement of this independence or ,,autonomy“ is fundamental in Kant's view to morality itself ${ }^{22}$ :

Now, with the idea of freedom the concept of autonomy is inseparably bound up, and with it the universal principle of morality, which in the idea lies at the foundation of all actions of rational beings, just as the law of nature lies at the foundation of all appearances.

This is the location of the greatest divergence between Jaar and Creed's artistic approaches towards fact. Creed's work, contrary to this model of transcendental freedom, seems keen, perhaps even desperate, to impart the same binding that exists between causality and objective knowledge to that between causality and freedom. The Kantian model that there is no objective practical knowledge, no way ,in which reason will settle the question of what to do" is recurrently presented in Creed's oeuvre as a source of troubling, nightmarish concern. ${ }^{23}$ Creed's practice suggests that he is not desirous of his own free action, his own agency, or at least that he is conflicted about his desire for it: he both wants, and doesn't want, to make something. While Jaar's work can be read as a use of causal objective knowledge in order to prompt a free agent to social action, Creed's can be read as a use of causal objective knowledge in order to avoid free will because of the responsibility it entails.

\section{The temporality of fact and its implications for responsibility}

If the order of the causal chain between fact and responsibility distinguishes the work of Jaar and Creed, it is configured differently again in Deller's practice. It is what it is presents a complex causal relationship between fact and responsibility: the repetitious nature of the title - William Safire has offered the term „tautophrase“ to describe such a statement ${ }^{24}$ - suggests a stagnant present tense in which temporality and causality are denied. The phrase is redolent with resignation and ambivalence: it asserts a refusal to interpret, a solid

\footnotetext{
$22 \quad$ Ibd., 62.

23 Scruton: Kant [note 18], 78.

24 William Safire: 'On Language', The New York Times, 2006,

http://www.nytimes.com/2006/03/05/magazine/305wwln_safire.1.html? r=1\&, accessed January 2015.
} 
determination neither to consider meaning, nor the impact of past on present or future. „It is what it is" rejects the effects of time, and so causality and responsibility become mute. Indeed, the repetition of the phrase presents the meaninglessness of fact without causality: tautology may present the ultimate fact, but its timelessness makes its meaning either everything or nothing. If the biblical „I am who I am, says the Lord“ suggests that meaning is beyond understanding, ,it is what it is“ suggests that meaning is fundamentally unwanted. ${ }^{25}$ Unlike Kant's statement that the end-point of causality entails the start-point of freedom and the moral choices it entails, here the temporality inherent in causality itself is denied, and so subsequent responsibility is also avoided. Deller's use of the phrase within his artwork, coupled with the painstaking neutrality of the project, leave him open to the accusation that this is the position he himself is taking: a blank retreat from interpretation and responsibility. As argued above, the artwork starts and ends with facts, from the fact of the car bomb to the facts of US citizens' responses. Yet while Deller's own reaction remains elusive, his interest in others' views echoes the Kantian temporality that Jaar's work espouses.

One of Deller's other most significant artworks, The Battle of Orgreave (2001), is also concerned with the causality of fact and shares a similar interest in repetition. As a filmed re-enactment of clashes between miners and police in South Yorkshire in the mid 1980s, The Battle of Orgreave is a manifestation of our desire to repeat, relive and reassess historic events. Historical re-enactment itself functions as something of a „tautophrase“, a repeated ,it is“. Actors, or as far as possible in Deller's case, those involved in the original event, strive to repeat moments from decades earlier in a reassertion of a previous time. The past is recreated as the past in the present. As with the grammatical flattening of temporality in „It is what it is“, The Battle of Orgreave suggests an attempt to compact past and present. Hume's dictum that the past does not necessarily resemble the future is undone: not only does the past resemble the future, but here it is the future, as if Deller is desirous of an 'eternal return'. The Battle of Orgreave attempts to open up a reassessment of the violent clash; it questions the view of history presented by accounts at the time, and so operates, as Deller had himself imagined, as a „crime scene“.${ }^{26}$ Again, this tautological approach to fact denies the causality that might lead to any one claim of responsibility: whose crime it is that is pushed back into the present is not stated by the artist.

\footnotetext{
$25 \quad$ Exodus 3:14, New International Version. Jeremy Deller: 'Jeremy Deller - Middle Class Hero', A Culture Show Special, BBC2, $24^{\text {th }}$ February 2012.
} 
For Jaar's Lights in the City, repetition functions not as an erasure of time or causality, however, but as an accumulation. The ongoing flashes of red from the Cupola signal a repeated fact, building over time. And yet, for Jaar, the repetition in this artwork is set within a context of a self-declared ,utopian thought"; in 2000, he expressed his hope that $^{27}$

Eventually all the shelters for homeless people in Montreal could be wired and connected to the Cupola. This way, a major landmark and historical monument in the city would be acting as a non-stop lighthouse, producing endless, painful distress signals to society. With enough media coverage and public outrage and support triggered by these ongoing distress signals, homelessness could be completely eradicated from Montreal.

This is a clear expression of a hope that the particular fact of homelessness in Montreal could be changed; the fact that returns could ultimately be ended: put out by its own fiery repetition. Indeed, this could be a breaking of 'fact' itself, since the returning nature of causality is at the heart of matters of fact. For Hume, all our understandings about fact are based on a misplaced trust in a repetitious future. As Peter Millican has noted, according to Hume „our beliefs about unobserved matters of fact are based on a general principle or supposition of uniformity, that the future will resemble, or be comfortable to, the past ${ }^{\mathrm{e} \text { c. }}{ }^{28}$ If this supposition is misguided, and we cannot assume that the future will „resemble“ the past, then what we have conceived of as fact will not stand. As outlined earlier, ultimately, Hume's argument ,that all our reasonings concerning matters of fact are derived from nothing but custom" led him to the conclusion that our belief in causation had no rational foundation. ${ }^{29}$ A.J. Ayer has read this argument not as a denial of the practical expectations we can hold on the basis of probability however, but rather as a realisation that we cannot attribute our interpretation of events to fact itself ${ }^{30}$ :

\footnotetext{
27 Alfredo Jaar: http://www.alfredojaar.net/index1.html, accessed 24/03/2014.

28 Peter Millican: 'Introduction', in David Hume: An Enquiry Concerning Human Understanding, Oxford 2007, xxxviii. 
The question at issue is not so much whether the future will resemble the past, since if the world is to continue to be describable at all, it must resemble it in some way or other, but how it will resemble it. What we want and cannot obtain, except by circular argument, is a justification for our actual interpretation of the lessons of the past; a justification for adhering to a special corpus of beliefs.

This seems to reflect Deller's approach to a large extent: his use of repetition re-poses questions about history within the present, as if the issue of interpretation is confined always only to the present tense and about the present time. And, as argued above, he seeks neither justification nor even a means of expression for his own interpretation.

Creed's oeuvre too reveals a fascination with temporality. Fully in line with his desire to avoid decisions, Creed has made works that are either very dependent upon repetition, or which avoid it at all costs: in Work No. 850 (2008) runners repeatedly pound the Duveen Gallery at Tate Britain every thirty seconds, Work No. 227 The lights going on and off (2000) sees the lights switch on and off repeatedly at regular intervals, while in Work No. 195 1-100 (1994-1995) Creed's band Owada refuse the repetition involved in music scores and instead sing ever onwards to 100 after the initial bar of „1,2,3,4“. Similarly, Creed has discussed his 2007 Work No. 739 Design for London Library lavatories, in which repetition was keenly avoided with every tile, tap, sink, fitting and fixture differing from each other, as a question of difficult decisions: to have them all the same would be „too much of a commitment“.31 Each response results from indecision: making is quickly followed by unmaking and vice versa, and choice is avoided ad infinitum, as if Creed is searching for an eternal return in order to settle the question of what to do. In his forward to the monograph Martin Creed Works, Creed advocates repeatedly ,starting ${ }^{632}$ :

It's easy to start, but it's hard to go on, and it's very difficult to finish. I hate endings. That is a start.

31 Martin Creed: Conversation between Sam Hecht and Martin Creed, London, 2 October 2008, http://www.iconeye.com/component/k2/item/3865-conversation-between-sam-hecht-and-martin-creed accessed October 2009. 
It's easy to say it's easy to start, but it's difficult too. It means choosing and feeling your way, being careful, worrying and guessing, creeping and peeping, and after interminable humming and haaing, plumping and dumping. I want to move in all directions at once: like a sound, or like a wave from a thrown stone.

At the start there is potential in all directions, 360 degrees of hope. You are free, and so maybe it is best to stay at the start. Stay still, stand there and throw things. Keep starting again and again, and never go on. Just keep making starts. Not false starts, but true starts that stop and start. Keep your options open. If you only ever start and never finish you can always hope and you can never lose.

Again, Creed's sentiments are in line with Ayer's reading of Hume: causality will give us no justification for our interpretation of the past, and so Creed opts to avoid seeking one. Rather, he recommends endlessly beginning, repeating the start, returning to the previous before. Such repetition will be grounded in the factual and will stop before the responsibility of interpreting or acting on the past can take hold.

Kant's divergence from Hume - his argument that objective knowledge conflates reason and experience, and his subsequent argument that causality applies only to the empirical realm and not to the transcendental realm, clearly suggests a very different view of the possibility of the justification and interpretation of past events. For Kant, causality too implies a sense of the temporal - of before and after - whereas the transcendental realm eludes such temporality altogether. ${ }^{33}$ The resulting theory of the categorical imperative describes a timeless 'ought' that is certainly implied in Jaar's Untitled (Newsweek), for example. Here facts prompt viewers not only to consider the possibility of interpretation, justification or action, but to face such reactions as a necessary responsibility.

Recent important writing on responsibility has come in the form of Judith Butler's Giving an Account of Oneself, whose argument that ,to take responsibility for oneself is to avow the limits of any self-understanding, and to establish these limits not only as a condition for the subject but as the predicament of the human community" is rather casually connected to Kantian thought: „I am not altogether out of the loop of the Enlightenment if I say, as I do,

33 Scruton, Kant [note 18], 82 
that reason's limit is the sign of our humanity. It might even be a legacy of Kant to say so" 34 Her thesis emphasises the role of the self in as much as the self is constituted through the actions of the Other and the wider social structure through which it is determined. In particular, Butler is interested in the way in which both Adorno and Foucault respond to Kant on ethics ${ }^{35}$ :

Although Adorno faults Kant for not recognising error as constitutive of the human and Foucault lauds him for apprehending precisely that, they both concur on the necessity of conceiving the human in its fallibility. If we are to act ethically, for either Adorno or Foucault, we must avow error as constitutive of who we are.

For Butler, then, both philosophers are „trying, in different ways, to dislodge the subject as the ground of ethics in order to recast the subject as a problem for ethics. “ 36 This is not to deny the significance of the subject, but rather to understand its formation and acceptance ${ }^{37}$ :

This is not the death of the subject, in either case, but an inquiry into the modes by which the subject is instituted and maintained, how it institutes and maintains itself, and how the norms that govern ethical principles must be understood as operating not only to guide conduct but to decide the question of who and what will be a human subject.

This argument of course resonates with Butler's separate study into the question of „when is life grievable?“ in which she argues that „norms of recognisability“ determine when life can be viewed as such, and therefore when it's end can be grieved over. ${ }^{38}$ Arguably both Jaar and Deller pose this very question about when life is grievable to their audiences. When (and where) is a victim of the Rwandan genocide, or a victim of the Al-Mutanabbi suicide bomb grieved for? Regardless of the positioning of their own subjecthood, both Jaar and Deller cause their viewers to consider this question by confronting them with the causality of fact.

\footnotetext{
$34 \quad$ Judith Butler: Giving an Account of Oneself, New York, 2005, 83. 
Ultimately, Butler's argument in Giving An Account of Oneself redirects the question of responsibility to another question: „How are we formed within social life, and at what cost?“39 Influenced by Levinas in particular, Butler details the complex, opaque and porous nature of the self ${ }^{40}$ :

If I become responsible only through being acted on by an Other, that is because the 'I" first comes into being as 'me' through being acted upon by an Other, and this primary impingement is already and from the start an ethical interpellation.

The social conditions in which such an „I“ emerges become dangerous when demanding an impossible degree of complete self-knowledge. Here Creed's presentation of his worrying, his 'humming and haaing' and self-doubt becomes not a short-sighted timidity but a foundational, even revolutionary response to a society that demands at least a veneer of assuredness and decisive self-belief.

The work of Jaar, Creed and Deller varies in key ways in their approach towards fact and its prompting of responsibility. Each approach presents a surprising interest in and reliance upon fact given the conventional acceptance that art practice is inherently bound up with the freedom of subjective creativity. However, that this same interest in causal objectivity causes each artist to reach such different ends only serves to demonstrate the severance of individual freedom from the laws of causality that preoccupy them. Ultimately, each practice contributes to the social matrix - even if predominantly a Western one - in which subjects are formed, injecting it with questions about responsible living in a global community. Each highlights a constitutive fallibility within the subject, be it a desire not to see or not to be seen; and each presents viewers with facts that prompt them to move beyond what Creed might term a ,start“".

\section{Afterword}

Before users can access the main index of Alfedo Jaar's website, the artist presents them with a quotation from William Carlos Williams, which emerges, letter by letter, as if

\footnotetext{
$39 \quad$ Butler, Giving an Account of Oneself [note 35], 136.

Ibd., 89.
} 
typed in real time in a font reminiscent of an old typewriter. The effect is that of 'news just in'. The famous quote emphasises both the advantages and difficulties of presenting fact through artistic means ${ }^{41}$ :

\author{
It is difficult \\ to get the news from poems \\ yet men die miserably every day \\ for lack
}

of what is found there.

That Jaar uses this quotation as a prelude to all of his artwork is notable: it acts as a statement of intent, perhaps a personal challenge. While adding to the urgency of his projects, and highlighting Jaar's persistent use of lack and absence as themes within his work, ,getting the news from poems“" is presented here as deeply valuable. As with fact and art, news and poetry are often viewed as existing in two distinct spheres, one concerned with neutral objectivity, the other with imaginative subjectivity. The former, it could be argued, deals with the external and the social, with the unfolding of physical events, while the latter deals with the internal, the interpretative, to put it poetically, the soul. Yet here poet and artist suggest that these two spheres cannot be viewed as separate, at least not without a severe cost. In this short extract, William Carlos Williams makes a large claim for the power of poetry, and, through quotation, Jaar makes a similar claim for the efficacy of contemporary art. The implication is that news, as an update of information, a collection of recent facts, is not enough on its own, and notably this statement is presented itself as both factual and poetic. Through their work, many contemporary artists including Jaar, Deller and Creed, echo this urgent claim to the conflation of art and fact.

\footnotetext{
$41 \quad$ William Carlos Williams: 'Asphodel, That Greeny Flower', quoted on Alfredo Jaar's website: http://alfredojaar.net/index1.html accessed December 2014.
} 